\title{
Effect of Phosphate Fertilization on Flooding Pampa Grasslands (Argentina)
}

\author{
Adriana M. Rodríguez, ${ }^{1}$ Elizabeth J. Jacobo, ${ }^{1}$ Pablo Scardaoni, ${ }^{2}$ and Victor A. Deregibus ${ }^{1}$ \\ Authors are ${ }^{1}$ Professors and ${ }^{2}$ Agronomist, Departamento de Producción Animal, Facultad de Agronomía, Universidad de Buenos Aires, Argentina.
}

\begin{abstract}
We postulate that phosphorus $(\mathrm{P})$ fertilization may increase above-ground net primary productivity $(A N P P)$ of rotationally grazed rangelands without reducing the legume component, as does $\mathrm{N}$ fertilization. In doing so, we evaluated the effect of phosphate fertilization on the production and relative contribution of legumes and grasses of native and old tall fescue (Festuca arundinacea Schreb) grasslands; we recorded annual production, seasonal productivity, and biomass contribution of each component. The experiment was conducted in a commercial farm located in the Flooding Pampa and managed under rotational grazing. Treatments consisted of two fertilization programs $\left(66\left(\mathrm{P}_{66}\right)\right.$ and $29\left(\mathrm{P}_{29}\right) \mathrm{kg} \mathrm{P} \cdot \mathrm{ha}^{-1}$ supplied as rock phosphate and/ or monoammonium phosphate from 1997 to 1999) and a nonfertilized control. A paddock dominated by native grassland and another dominated by old tall fescue grassland were selected. Nine 5-ha plots were established in each paddock, and treatments were randomly assigned. During the experimental period, from October 1998 to October 1999, total above-ground biomass was harvested from each plot before and after each grazing period and separated into components: tall fescue, other $\mathrm{C}_{3}$ perennial grasses, legumes, $\mathrm{C}_{3}$ annual grasses, $\mathrm{C}_{4}$ grasses, forbs, and standing dead material. ANPP of each component was estimated during the warm (October 1998-February 1999) and the cool (March 1999-September 1999) season. In native grassland, phosphate fertilization increased $A N P P$ of $\mathrm{C}_{3}$ annual grasses and legumes during both the warm and the cool seasons; therefore annual ANPP of the grassland under $\mathrm{P}_{66}$ was $40 \%$ higher than under $\mathrm{P}_{29}$ and doubled ANPP of nonfertilized plots. Phosphate fertilization didn't increase total annual ANPP of old tall fescue grassland, but it did increase ANPP of legumes during both seasons.
\end{abstract}

\section{Resumen}

Postulamos que la fertilización fosforada permitiría incrementar la productividad primaria neta aérea (PPNA) de pastizales naturales y pasturas viejas dominadas por festuca sin afectar la contribución de las leguminosas, como ocurre cuando se fertiliza con nitrógeno. Para ello, se comparó la productividad estacional y anual así como la contribución de gramíneas y leguminosas en cada recurso, con distintos programas de fertilización: dos niveles de fósforo (66 y $29 \mathrm{~kg} \mathrm{de} \mathrm{P} \cdot \mathrm{ha}^{-1}$ adicionados como roca fosfatada y/o fosfato monoamónico en sucesivas aplicaciones entre 1997 y 1999) y un control sin fertilización. El experimento se llevó a cabo en un establecimiento manejado con pastoreo rotativo ubicado en la Pampa Inundable, donde se seleccionaron dos potreros, uno de pastizal natural y otro de pastura dominada por festuca. En cada potrero se establecieron 9 parcelas de 5 ha a las que se asignaron al azar los tratamientos. Entre octubre de 1998 y octubre de 1999 se cosechó la biomasa de cada parcela antes y después de cada pastoreo y se separó en: festuca, otras gramíneas $\mathrm{C}_{3}$ perennes, leguminosas, gramíneas $\mathrm{C}_{3}$ anuales, gramíneas $\mathrm{C}_{4}$, dicotiledóneas y material muerto de cada componente. Se calculó la PPNA durante la estación cálida (octubre 1998 a febrero 1999) y durante la estación fresca (marzo a setiembre de 1999). En los pastizales naturales, la fertilización fosforada incrementó la productividad de las gramíneas $\mathrm{C}_{3}$ anuales y de las leguminosas en ambas estaciones. La adición de $\mathrm{P}_{66}$ duplicó la PPNA anual del control y superó en un $40 \%$ a la obtenida con adición de $\mathrm{P}_{29}$. La fertilización fosforada no incrementó la PPNA total de las pasturas viejas de festuca, pero aumentó la PPNA de leguminosas en ambas estaciones.

Key Words: forage productivity, grasses, legumes, phosphorus, tall fescue, temperate native grasslands

\section{INTRODUCTION}

The Flooding Pampa is a $90000-\mathrm{km}^{2}$ region of grasslands in the eastern portion of central Argentina. Angus and Hereford cow/calf operation is the dominant economic activity with an average secondary production of $70 \mathrm{~kg}$ meat $\cdot \mathrm{ha}^{-1} \cdot \mathrm{y}^{-1}$. The region is characterized by a mild, humid climate with lowfertility soils (Soriano et al. 1991). The flat relief and the occurrence of a high water table determine frequent flooding

This research was funded by the National Council of Research Argentina (CONICET).

Correspondence: Adriana Rodríguez, Departamento de Producción Animal, Facultad de Agronomía, Universidad de Buenos Aires, Av. San Martín 4453 (C1417DSE), Buenos Aires, Argentina. Email: arodrigu@agro.uba.ar

Manuscript received 7 June 2006; manuscript accepted 8 June 2007. events. Native grasslands are the main forage resources, although a portion of them were replaced by mixed pastures more than 20 years ago. As the renewal of these pastures is not recommended because of soil restrictions, only tall fescue (Festuca arundinacea Schreb) and tall wheatgrass (Thinopyrum ponticum [Podp.]; Z.-W. Liu \& R.-C. Wang) persist like naturalized components.

The favorable climate condition allows sequential growth of $\mathrm{C}_{3}$ and $\mathrm{C}_{4}$ grasses during the cool and warm seasons, respectively. However, forage production follows a seasonal pattern, since maximum growth rate occurs in late spring (30$80 \mathrm{~kg} \mathrm{DM} \cdot \mathrm{ha}^{-1} \cdot \mathrm{d}^{-1}$ ), while minimum growth rate occurs in winter (3-10 kg DM $\cdot \mathrm{ha}^{-1} \cdot$ day $^{-1}$; Sala et al. 1981; Oesterheld and León 1987). The shortage of forage during winter restricts the carrying capacity of this system (Deregibus et al. 
1995). This restriction may be overcome by applying a rotational grazing methodology that promotes early establishment of annual ryegrass (Lolium multiflorum Lam.), the most important winter annual grass of these rangelands (Jacobo et al. 2000), or via nitrogen fertilization (Fernández Greco and Agnusdei 2004). Both alternatives reduce seasonal variability by increasing winter forage production.

It is known that grassland production depends mainly on the availability of nitrogen $(\mathrm{N})$, but $\mathrm{N}$ fertilization negatively affects legume cover in both cultivated and native grasslands (Lee and Lee 2000; Aydin and Uzun 2005). In Flooding Pampa grasslands, where legumes are a valuable but scarce component (Jacobo et al. 2006), $\mathrm{N}$ addition reduces their contribution (Bustos et al. 1998) and may cause their disappearance (Ginzo et al. 1982).

In humid or subhumid rangelands, phosphate fertilization drastically increases biomass production when legumes are an important component of the community (Henkin et al. 1996; Osman et al. 1999), lightly increases production when legumes are a minor component of rangeland community (Nichols et al. 1990; Brockway et al. 1998), and doesn't affect production when grasses are dominant (Kalmbachet and Martin 1996). At the Flooding Pampa, there is no conclusive evidence. Some research shows that phosphorus $(\mathrm{P})$ fertilization doesn't increase biomass production (Ginzo et al. 1982; Mendoza et al. 1983; Costa and García 1997) although legumes increase their contribution in some cases (Ginzo et al. 1982); while other research shows that $\mathrm{P}$ fertilization increases spring-summer productivity as well as legume and winter annual grass contribution (Collantes et al. 1998).

At ecosystem scale, addition of $P$ is necessary to avoid net losses of this nutrient at any sustainable stocking rate in Flooding Pampa grasslands. Nonfertilized grasslands at low stocking rate $\left(0.55 \mathrm{AU} \cdot \mathrm{ha}^{-1}\right)$ accrues $\mathrm{N}$ at rates of $3-7 \mathrm{~kg}$ $\mathrm{N} \cdot \mathrm{ha}^{-1} \cdot \mathrm{y}^{-1}$ but loses $\mathrm{P}$ at a rate of $0.4 \mathrm{~kg} \mathrm{P} \cdot \mathrm{ha}^{-1} \cdot \mathrm{y}^{-1}$ (Chaneton et al. 1996). At higher stocking rates, net losses of both $\mathrm{N}\left(2.2 \mathrm{~kg} \mathrm{~N} \cdot \mathrm{ha}^{-1} \cdot \mathrm{y}^{-1}\right)$ and $\mathrm{P}\left(45 \mathrm{~kg} \mathrm{P} \mathrm{ha}^{-1} \cdot \mathrm{y}^{-1}\right)$ are expected (Rubio et al. 1997).

Considering the foregoing, we postulate that $\mathrm{P}$ fertilization of rotationally grazed rangeland may increase winter forage production and legume contribution, allowing an increase in the carrying capacity of the rangeland. The aim of this work is to evaluate the effect of phosphate fertilization on the production and relative contribution of legumes and grasses of the principal forage resources of the Flooding Pampa: 1) the most conspicuous native community, where annual ryegrass is a common component, and 2) an old pasture dominated by tall fescue. In doing so, we measured annual production, seasonal productivity, and biomass contribution of each component, under three different $\mathrm{P}$ fertilization programs.

\section{METHODS}

\section{Study Area}

The regional climate of the Flooding Pampa is temperate subhumid with mean annual precipitation varying from $1000 \mathrm{~mm}$ in the north to $850 \mathrm{~mm}$ in the south, evenly distributed throughout the year. Monthly temperatures range from $6.8^{\circ} \mathrm{C}$ in July-August to $21.8^{\circ} \mathrm{C}$ in January. Because of the

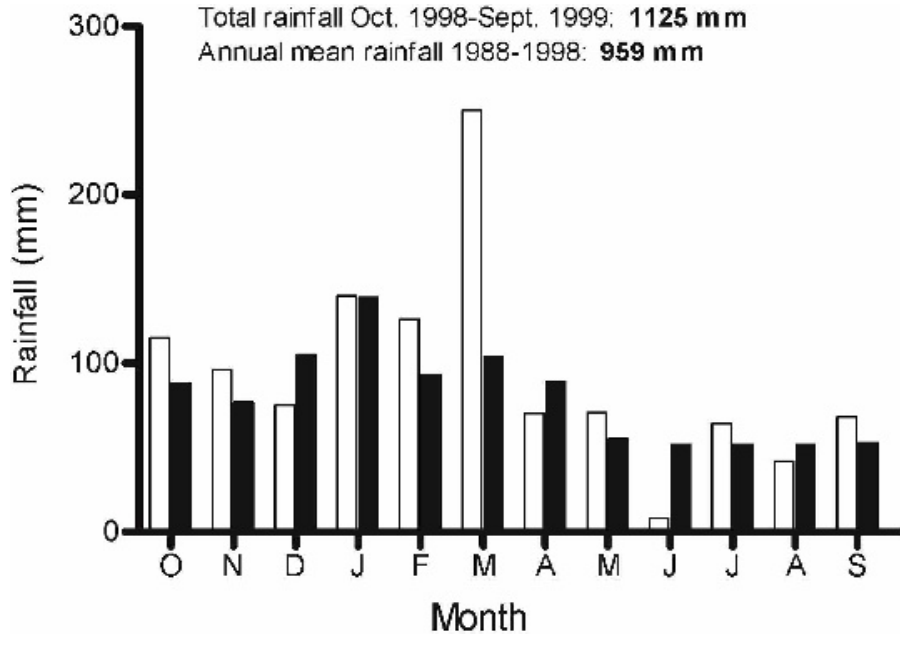

Figure 1. Monthly rainfall $(\mathrm{mm})$ during the experimental period (empty bars) and average monthly rainfall from 1988 to 1998 (black bars).

flat relief and the occurrence of a high water table, most soils belong to the halo-hydromorphic complexes and associations influenced by flooding (Natraquols, Natracualfs, Natralbols, and Argialbols). Well-drained soils (Hapludols and Argiudols) are restricted to the highest landscape areas, where pastures and crops are cultivated. Vegetation is arranged as a complex mosaic of herbaceous communities mainly determined by landscape features (Perelman et al. 2001).

The experiment was carried out on a commercial farm located at long $36^{\circ} 15^{\prime} \mathrm{S}$, lat $60^{\circ} 35^{\prime} \mathrm{W}$, at an elevation of $80 \mathrm{~m}$ above sea level in the center of Flooding Pampa region. The area of the farm is about 2500 ha for Angus and Hereford cow-calf operations and breeding of a portion of calves. Native grasslands are the main forage resources. Almost 800 ha were replaced by mixed pastures 15 years ago, but only tall fescue persisted. Since 1996, rotational grazing has been performed by concentrating herds of 400-500 breeding cows (Angus and Hereford), which sequentially have grazed a series of 10-12 paddocks with an average size of 50 ha. The average weight of cows was $420 \mathrm{~kg}$. The breeding season ran from November to January, and calves were weaned during April (6-8 months of age) with an average weight of $170 \mathrm{~kg}$. The occupation period in each paddock varied between 3 and 15 days, and the rest period varied between 25 and 90 days according to the growth rate of major forage species. Grazing intensity was high during autumn and winter, so nearly all the available biomass was removed in each occupation period. During spring and summer, grazing intensity was lower to allow improving body condition of cattle for breeding and lactation (Deregibus et al. 1995).

Rainfall was recorded monthly with a Hellman Rain Gage. Rainfall during the study was greater than the 10 -year average rainfall (Fig. 1). Nevertheless, because of the high topographic position of the paddocks, there was no significant flooding.

\section{Experimental Design}

Two paddocks of 50 ha were selected. One of them corresponded to a native grassland dominated by Lolium multiflorum Lam., Paspalum dilatatum Poir., Bothriochloa laguroides (DC) Herter, Sporobolus indicus (L.) R. Br., Panicum 
milioides Nees ex Trin., Stipa neesiana Trin. \& Rupr., Briza subaristata Lam., Piptochaetium montevidensis (Spreng.) Parodi, and Danthonia montevidensis Hack. \& Arechav. (B community; León 1975). The other paddock corresponded to a pasture sown 15 years ago where the main component was tall fescue (F. arundinacea). The topographic position of both paddocks was relatively high. Soils of both paddocks were typical Natracuols ( $\mathrm{pH} 5.9$, electrical conductivity $0.4 \mathrm{mmho} \cdot \mathrm{cm}^{-1}$, P content $4 \mathrm{ppm}$, and $\mathrm{N}$ content $0.301 \%$ in the $0-0.15 \mathrm{~m}$ layer). Each paddock was subdivided in 9 (5ha) plots, and treatments were randomly assigned to each plot. Treatments consisted of two fertilization programs $\left(66\left[\mathrm{P}_{66}\right]\right.$ and $29\left[\mathrm{P}_{29}\right] \mathrm{kg} \mathrm{P} \cdot \mathrm{ha}^{-1}$ supplied as rock phosphate and/or monoammonium phosphate from 1997 to 1999) and a nonfertilized control. The higher $\mathrm{P}$ fertilization program $\left(\mathrm{P}_{66}\right)$ consisted of the application of $200 \mathrm{~kg} \cdot \mathrm{ha}^{-1}$ rock phosphate (RP) and $80 \mathrm{~kg} \cdot \mathrm{ha}^{-1}$ of monoammonium phosphate (MAP) in September 1997, $80 \mathrm{~kg} \cdot \mathrm{ha}^{-1}$ MAP in September 1998, and $40 \mathrm{~kg} \cdot \mathrm{ha}^{-1} \mathrm{MAP}$ in April 1999. This program supplied 36.7, 19.2, and $9.6 \mathrm{~kg} \mathrm{P} \cdot \mathrm{ha}^{-1} \cdot \mathrm{y}^{-1}$ in the successive years, representing an overall dose of $66 \mathrm{~kg} \mathrm{P} \cdot \mathrm{ha}^{-1}$. The lower $\mathrm{P}$ dose fertilization program $\left(\mathrm{P}_{29}\right)$ consisted of the application of $80 \mathrm{~kg} \cdot \mathrm{ha}^{-1}$ MAP in September 1998 and $40 \mathrm{~kg} \cdot \mathrm{ha}^{-1}$ MAP in April 1999. This program supplied 19.2 and $9.6 \mathrm{~kg}$ $\mathrm{P} \cdot \mathrm{ha}^{-1} \cdot \mathrm{y}^{-1}$ in the successive years, representing an overall dose of $29 \mathrm{~kg} \mathrm{P} \cdot \mathrm{ha}^{-1}$. These $\mathrm{P}$ doses were determined based on previous experimental research in these grasslands (Mendoza et al. 1983; Collantes et al. 1998). The experimental design was completely randomized with three replicates.

We used rock phosphate as a source of $\mathrm{P}$ attending to the increasing awareness about the impact of chemical fertilizers on the environment. This insoluble fertilizer slowly becomes available in acid soils $(\mathrm{pH}<6.2)$, and is recommended for perennial crops or forage resources that do not require immediate availability. When rock phosphate is strategically combined with a periodic supply of a $\mathrm{P}$ soluble source, this allows a gradual increase of the P pool (Melgar and Castro 2005). Monoammonium phosphate was also applied as a source of $\mathrm{P}$. As this fertilizer contains around $11 \% \mathrm{~N}$, total $\mathrm{N}$ fertilization was 4.4 or $8.8 \mathrm{~kg} \mathrm{~N} \cdot \mathrm{ha}^{-1} \cdot \mathrm{y}^{-1}$. Considering that Natracuol soils in this region contain around $44 \mathrm{~kg}$ $\mathrm{NO}_{3}-\mathrm{N}+\mathrm{NH}_{4}-\mathrm{N} \mathrm{ha}^{-1}$ (Taboada and Lavado 1986; Chaneton et al. 1996), this low rate of $\mathrm{N}$ caused a negligible increase in the mineral $\mathrm{N}$ soil pool. For this reason, available response curves of forage production to $\mathrm{N}$ addition developed for these grasslands don't include $\mathrm{N}$ levels lower than $50 \mathrm{~kg} \cdot \mathrm{ha}^{-1} \cdot \mathrm{y}^{-1}$. These curves show a linear response between 50 and $150 \mathrm{~kg} \mathrm{~N} \cdot \mathrm{ha}^{-1} \cdot \mathrm{y}^{-1}$ with a $\mathrm{N}$ efficiency use of around $23 \mathrm{~kg} \mathrm{DM} \cdot \mathrm{kg}^{-1} \mathrm{~N}$ applied. The extrapolation of $\mathrm{N}$ supply of 4.4 or $8.8 \mathrm{~kg} \mathrm{ha}^{-1} \cdot \mathrm{y}^{-1}$ using this curve (assuming the limitation of this operation) may cause only a negligible increment of forage production $(100$ or $200 \mathrm{~kg}$ $\left.\mathrm{DM} \cdot \mathrm{ha}^{-1} \cdot \mathrm{y}^{-1}\right)$. Therefore, in this study $\mathrm{N}$ effects are not considered.

\section{Sampling and Data Arrangement}

During the experimental period, which comprised a complete growing cycle (from October 1998 to October 1999), paddocks were grazed in November 1998, December 1998, February
1999, June 1999, and October 1999. Total above-ground biomass was harvested from the 9 plots ( 3 plots per treatment) of each paddock before and after each occupation period. Ten $0.25-\mathrm{m}^{2}$ areas (subsamples) were randomly located and clipped to $2 \mathrm{~cm}$ height on each date. Subsamples from each plot were composited to obtain a single sample. Samples from the native grassland were hand separated into six components: legumes, $\mathrm{C}_{3}$ annual grasses, $\mathrm{C}_{3}$ perennial grasses, $\mathrm{C}_{4}$ grasses, forbs, and standing dead material. Samples from the old tall fescue grassland were separated into the same components plus the tall fescue fraction. Samples then were oven dried at $70^{\circ} \mathrm{C}$ until constant weight and weighed.

Daily above ground net primary productivity (ANPP) of each component was estimated applying a procedure proposed by Sala et al. (1981) that considers a standing dead biomass term in order to reduce the masking effect of senescence in the estimation of productivity. The difference between the accumulated green biomass of a component at the end of a rest period and the remnant biomass left after the previous occupation period $(\triangle G B)$ and the difference of standing dead biomass of this component registered between the end of a rest period and the end of the previous occupation period $(\Delta S D)$ were calculated as follows:

$$
\text { Daily } A N P P=(\triangle G B+\Delta S D) / \text { Rest period }(\text { days })
$$

when $\triangle G B>0$ and $\triangle S D>0$, or

$$
\text { Daily } A N P P=(\triangle S D-|\Delta G B|) / \text { Rest period(days) }
$$

when $\Delta G B<0, \Delta S D>0$, and $\Delta S D>|\Delta G B|$.

The seasonal variation of ANPP of each component under different $\mathrm{P}$ fertilization programs was compared grouping $A N P P$ data obtained from the rest periods during the warm season (October 1998-February 1999) and those during the cool season (March 1999-September 1999). Annual production was estimated as the summation of the ANPP of five rest periods multiplied by the duration of the corresponding period, considering that biomass growth was negligible during the brief occupation periods.

\section{Statistical Analysis}

As most variables showed lack of normality, the Kruskal-Wallis test by ranks was used to analyze the effect of phosphate fertilization on seasonal ANPP of each component and on total above ground annual production of both the native and the old tall fescue grasslands. Dunn's multiple comparison test $(P<0.05)$ was used to detect differences among treatments.

\section{RESULTS}

Phosphate fertilization increased ANPP of $\mathrm{C}_{3}$ annual grasses and legumes of the native grassland during both the warm and the cool season (Fig. 2). During the warm season, ANPP of $\mathrm{C}_{3}$ annual grasses increased at higher $\mathrm{P}$ levels, and ANPP of legumes increased only at the highest $\mathrm{P}$ level (Fig. 2A). During the cool season, ANPP of $\mathrm{C}_{3}$ annual grasses increased only at the highest $\mathrm{P}$ level, and ANPP of legumes increased at any $\mathrm{P}$ 


\section{A. Warm season}

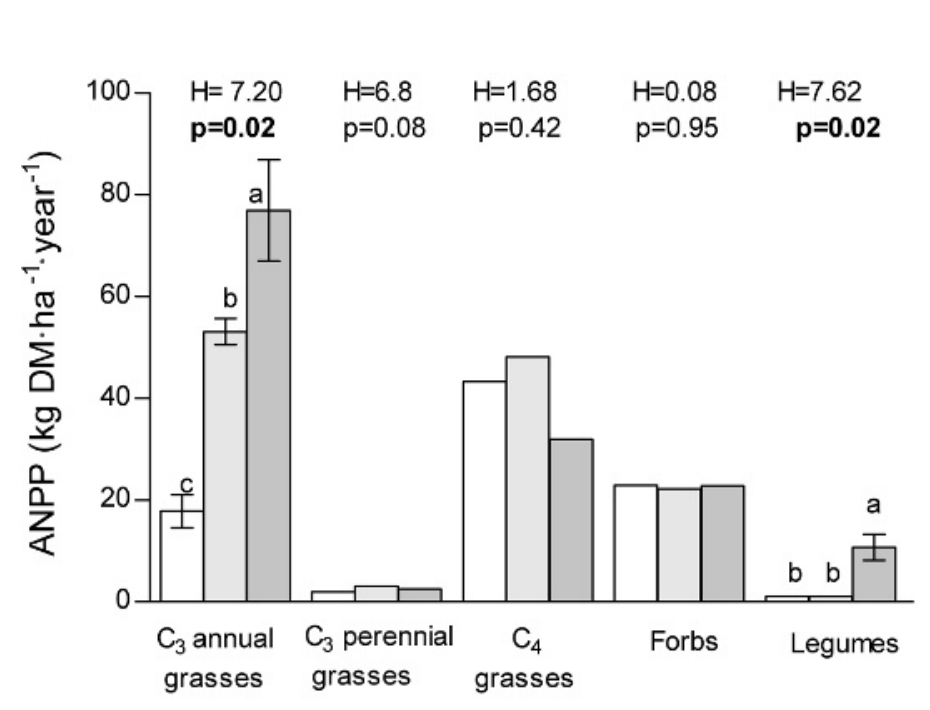

B. Cool season

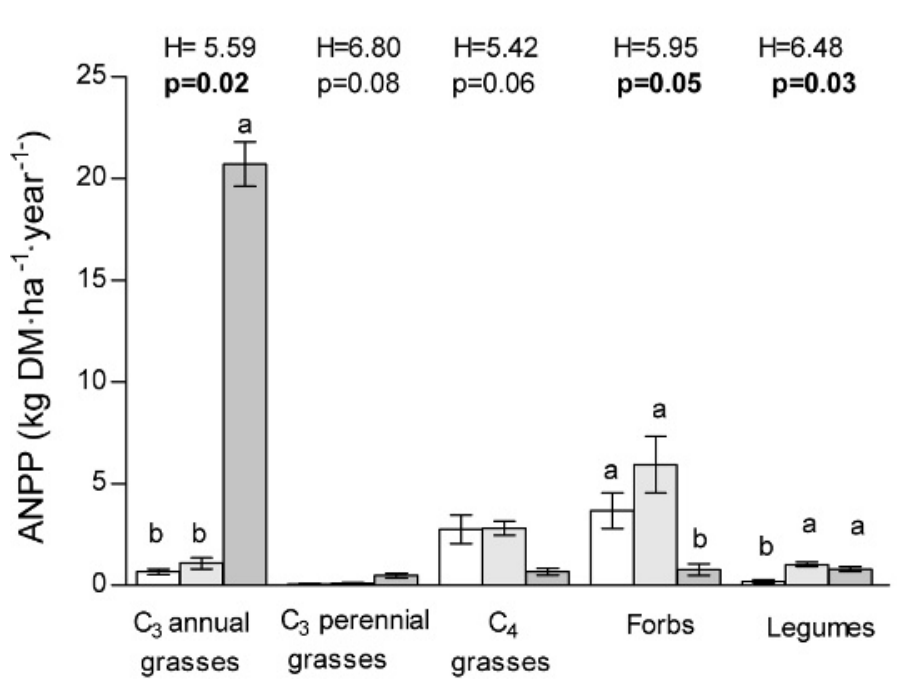

Figure 2. Above ground net primary productivity (ANPP) of each vegetation component of the native grassland during the warm $(\mathbf{A})$ and the cool (B) season under different $P$ fertilization treatments: $P_{0}$ (empty bars), $P_{29}$ (light gray bars), and $P_{66}$ (dark gray bars). $H$ statistic and $P$ value from Kruskal-Wallis test are above each vegetation component; letters indicate significant differences among treatments when found within vegetation component. Vertical lines indicate standard errors.

level (Fig. 2B). Application of $\mathrm{P}$ did not affect ANPP of perennial grasses (both $\mathrm{C}_{3}$ and $\mathrm{C}_{4}$ ) at any season (Figs. $2 \mathrm{~A}$ and 2B). ANPP of forbs decreased at the highest $\mathrm{P}$ level during the cool season (Fig. 2B).

In the old tall fescue grassland, the biomass of $\mathrm{C}_{3}$ annual grasses and $\mathrm{C}_{3}$ perennial grasses other than tall fescue was negligible in both nonfertilized controls and fertilized treatments, so they were not plotted in Figure 3. Phosphate fertilization didn't change ANPP of tall fescue, but it did affect $A N P P$ of legumes and forbs during both the warm and the cool

\section{A. Warm season}

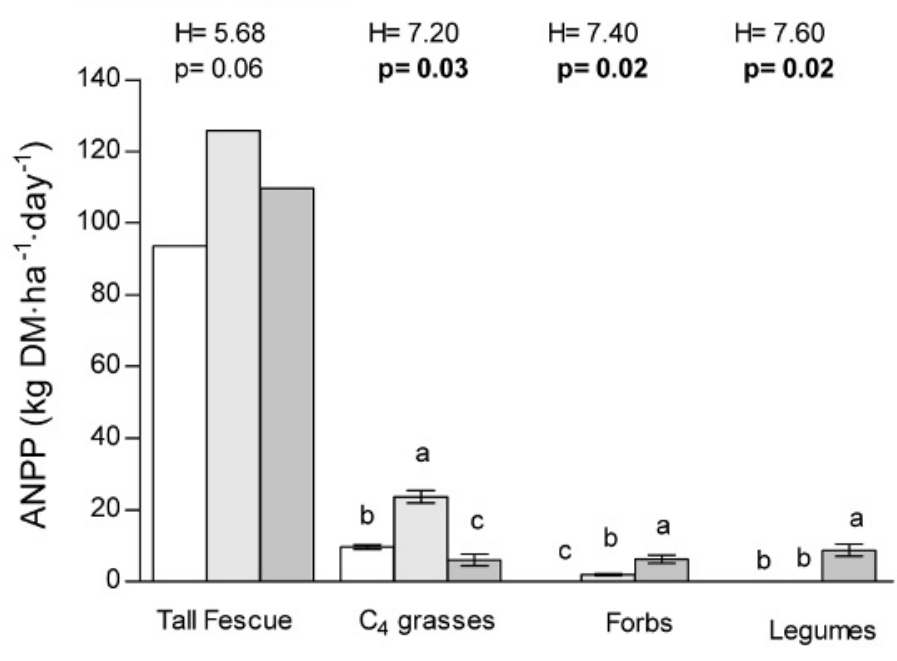

\section{B. Cool season}

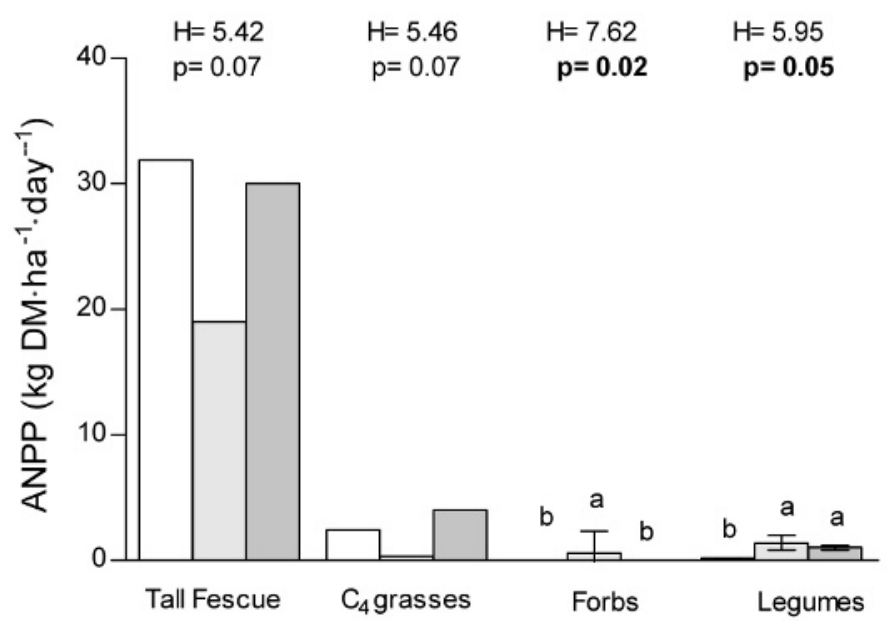

Figure 3. Above ground net primary productivity (ANPP) of each vegetation component of the old tall fescue grassland during the warm (A) and the cool (B) season under different $P$ fertilization treatments: $P_{0}$ (empty bars), $\mathrm{P}_{29}$ (light gray bars), and $\mathrm{P}_{66}$ (dark gray bars). $H$ statistic and $P$ value from Kruskal-Wallis test are above each vegetation component; letters indicate significant differences among treatments when found within vegetation component. Vertical lines indicate standard errors.

season and of $\mathrm{C}_{4}$ grasses during the warm season (Fig. 3). $A N P P$ of legumes increased only at the highest $\mathrm{P}$ level during the warm season (Fig. 3A) and at any P level during the cool season (Fig. 3B). During the warm season, ANPP of forbs increased at higher $\mathrm{P}$ doses (Fig. 3A) but in the cool season $A N P P$ was highest at $\mathrm{P}_{29}$ (Fig. 3B). The highest ANPP of $\mathrm{C}_{4}$ grasses was performed at $\mathrm{P}_{29}$ (Fig. 3A).

As a consequence of these responses, total annual above ground production of native grassland under $\mathrm{P}_{66}$ was $40 \%$ higher than the production measured under $\mathrm{P}_{29}$ and doubled the production obtained in nonfertilized plots (Table 1 ). The most responsive component of the native grassland was $\mathrm{C}_{3}$ annual grasses (made up by almost $80 \%$ L. multiflorum), 
Table 1. Annual above ground net primary productivity (ANPP) of each vegetation component of the native grassland and total ANPP (kg $\left.\mathrm{DM} \cdot \mathrm{ha}^{-1} \cdot \mathrm{y}^{-1}\right)$ under different $\mathrm{P}$ fertilization treatments. Different letters indicates significant differences among fertilization treatments within components $(P<0.05)$.

\begin{tabular}{lcccccc}
\hline P treatment & & $C_{3}$ perennial & & & \\
grasses & $C_{3}$ annual grasses & grasses & Legumes & Forbs & Total \\
\hline $\mathrm{P}_{0}$ & $613 \mathrm{c}$ & 68 & 1895 & $25 \mathrm{~b}$ & $1290 \mathrm{ab}$ & $3891 \mathrm{c}$ \\
$\mathrm{P}_{29}$ & $1724 \mathrm{~b}$ & 104 & 2062 & $120 \mathrm{~b}$ & $1466 \mathrm{a}$ & $5478 \mathrm{~b}$ \\
$\mathrm{P}_{66}$ & $4988 \mathrm{a}$ & 132 & 1312 & $502 \mathrm{a}$ & $877 \mathrm{~b}$ & $7814 \mathrm{a}$ \\
\hline
\end{tabular}

which increased above ground annual production almost 2-fold under $\mathrm{P}_{29}$ and 8 -fold under $\mathrm{P}_{66}$ respective to nonfertilized plots (Table 1). Legumes (mainly Lotus tenuis) also increased above ground annual production almost 5-fold under $\mathrm{P}_{29}$ and 20-fold under $\mathrm{P}_{66}$ respective to nonfertilized plots (Table 1 ). $\mathrm{P}_{66}$ affected forb production, which decreased around 50\% respective to $\mathrm{P}_{29}$ and $\mathrm{P}_{0}$. Above ground annual production of perennial $\mathrm{C}_{3}$ and $\mathrm{C}_{4}$ grasses did not respond to $\mathrm{P}$ fertilization (Table 1).

Contrasting to the native grassland, total above ground annual production of old tall fescue grassland didn't vary because tall fescue, which contributed $85 \%$ of pasture production, was not affected by P fertilization (Table 2). However, above ground annual production of legumes (mainly Trifolium repens) increased almost 8-fold under $\mathrm{P}_{29}$ and 23-fold under $\mathrm{P}_{66}$ respective to nonfertilized plots (Table 2). Forbs were not registered in nonfertilized plots, but they contributed $1.7 \%$ and $2.8 \%$ in $\mathrm{P}_{29}$ and $\mathrm{P}_{66}$, respectively, to the annual production (Table 2). $\mathrm{C}_{4}$ grasses above ground annual production was higher in $\mathrm{P}_{29}$ than in $\mathrm{P}_{66}$ and $\mathrm{P}_{0}$ (Table 2).

\section{DISCUSSION}

The main result of this experiment shows that $\mathrm{P}$ fertilization in rotational grazed grasslands significantly increases the productivity of legumes and $\mathrm{C}_{3}$ annual grasses when this component preexists in the community, but it doesn't affect either $\mathrm{C}_{3}$ or $\mathrm{C}_{4}$ perennial grass production. Therefore, the old tall fescue grassland doesn't increase overall production while the native grassland dominated by the $\mathrm{C}_{3}$ annual grass $L$. multiflorum reaches a much higher overall production with $\mathrm{P}$ fertilization. Furthermore, in both native and old tall fescue grassland, a higher contribution of legumes is obtained with $\mathrm{P}$ addition. Similar high overall production of native grassland was obtained when $\mathrm{N}$ was applied at doses of $150 \mathrm{~kg} \mathrm{~N} \cdot \mathrm{ha}^{-1}$ or higher (Fernandez Grecco et al. 1995; Fernandez Grecco and Mazzanti 1998).

It is usually accepted that $\mathrm{P}$ fertilization increases forage production by increasing legume productivity of cultivated and native grasslands (Henkin et al. 1996; Osman et al 1999; Whitehead 2000). However, the increase in forage production of around $100 \%$ in $\mathrm{P}_{66}\left(7814 \mathrm{~kg} \mathrm{DM} \cdot \mathrm{ha}^{-1} \cdot \mathrm{y}^{-1}\right)$ and $40 \%$ in $\mathrm{P}_{29}\left(5468 \mathrm{~kg} \mathrm{DM} \cdot \mathrm{ha}^{-1} \cdot \mathrm{y}^{-1}\right)$ relative to nonfertilized native grassland $\left(3891 \mathrm{~kg} \mathrm{DM} \cdot \mathrm{ha}^{-1} \cdot \mathrm{y}^{-1}\right)$ reported here was a consequence of the responsiveness of L. multiflorum, a cool season annual grass. This species contributed around of $80 \%$ of the primary production of $\mathrm{C}_{3}$ annual grasses, the component that increased from $600 \mathrm{~kg} \mathrm{DM} \cdot \mathrm{ha}^{-1} \cdot \mathrm{y}^{-1}$ in nonfertilized grassland to 1800 and $4600 \mathrm{~kg} \mathrm{DM} \cdot \mathrm{ha}^{-1} \cdot \mathrm{y}^{-1}$ when 29 and $66 \mathrm{~kg}$ $\mathrm{P} \cdot \mathrm{ha}^{-1}$ were added, respectively. Collantes et al. (1998) also found that $\mathrm{P}$ addition increased native grassland production when L. multiflorum was an important component, but at a lower $\mathrm{P}$ use efficiency $\left(28 \mathrm{~kg} \mathrm{DM} \cdot \mathrm{ha}^{-1} \cdot \mathrm{y}^{-1} \mathrm{P}\right.$ added) than that obtained in our experiment $\left(60 \mathrm{~kg} \mathrm{DM} \cdot \mathrm{ha}^{-1} \cdot \mathrm{y}^{-1} \mathrm{P}\right.$ added). In contrast, when $\mathrm{C}_{3}$ grasses were represented by other annuals like Gaudinia fragilis (L.) Beauv. (Mendoza et al. 1983) or by perennials (Ginzo et al. 1982), P addition didn't affect forage production. ANPP of perennial $\mathrm{C}_{4}$ grasses didn't vary significantly at any level of $\mathrm{P}$ fertilization, although their relative contribution decreased from $49 \%$ in nonfertilized treatment to $17 \%$ in $\mathrm{P}_{66}$, with the concomitant increase of the ANPP of $\mathrm{C}_{3}$ annual grasses. This lack of consistent response of perennial grasses to $\mathrm{P}$ addition has already been shown (Mendoza et al. 1983; Collantes et al. 1998). These results contribute to the hypothesis that $L$. multiflorum would be considered as a key species of the Flooding Pampa rangelands (Rodríguez 2004).

Several features converge to explain the responsiveness of $L$. multiflorum to $\mathrm{P}$ fertilization in grasslands under the rotational grazing used in this experiment:

1) L. multiflorum has a much shallower rooting system than perennial grasses (Durand et al. 1997), which confers a competitive advantage to absorb P from the superficial soil horizon.

2) As natural reseeding is the crucial mechanism to ensure persistence of L. multiflorum, the high $\mathrm{P}$ availability in the superficial soil horizon allows seedling establishment. In contrast, this is a minor mechanism for the persistence of perennial grasses.

Table 2. Annual above ground net primary productivity (ANPP) of each vegetation component of old tall fescue grassland and total ANPP (kg $\left.\mathrm{DM} \cdot \mathrm{ha}^{-1} \cdot \mathrm{y}^{-1}\right)$ under different $\mathrm{P}$ fertilization treatments. Different letters indicates significant differences among fertilization treatments within components $(P<0.05)$.

\begin{tabular}{lccrrr}
\hline $\mathrm{P}$ treatment & Tall fescue & $\mathrm{C}_{4}$ grasses & Legumes & Forbs & Total \\
\hline $\mathrm{P}_{0}$ & 7145 & $611 \mathrm{ab}$ & $20 \mathrm{c}$ & $0 \mathrm{c}$ & 7767 \\
$\mathrm{P}_{29}$ & 6397 & $1047 \mathrm{a}$ & $160 \mathrm{~b}$ & $140 \mathrm{~b}$ & 7925 \\
$\mathrm{P}_{66}$ & 7397 & $301 \mathrm{~b}$ & $465 \mathrm{a}$ & $238 \mathrm{a}$ & 8343 \\
\hline
\end{tabular}


3) L. multiflorum exhibits a higher growth rate than other grasses of the Flooding Pampa grassland (Cahuepé and Hidalgo 1991; Colabelli et al. 1998; Agnusdei 1999), and therefore a higher rate of nutrient uptake may be expected. In fact, it exhibits higher $\mathrm{P}$ and $\mathrm{N}$ removal rates than other species (Abe and Ozaki 1998).

4) $\mathrm{P}$ fertilization increases leaf elongation rates of $L$. multiflorum (Ferreira de Quadros et al. 2005).

5) Rotational grazing promotes an earlier germination and seedling establishment of $L$. multiflorum (Jacobo et al. 2000), and therefore biomass accumulation occurs over a longer growing period.

As a consequence of the significant ANPP increase of $\mathrm{C}_{3}$ annual grasses under the addition of $\mathrm{P}$, the seasonal distribution of forage was modified. In nonfertilized native grassland, the highest growing rate was around $50 \mathrm{~kg} \mathrm{DM} \cdot \mathrm{ha}^{-1} \cdot \mathrm{d}^{-1}$ in late spring, and the lowest was around $2.5 \mathrm{~kg} \mathrm{DM} \cdot \mathrm{ha}^{-1} \cdot \mathrm{d}^{-1}$ in late winter, similar to those found in this community by other authors (Sala et al. 1981; Hidalgo and Cahuépé 1991). In $\mathrm{P}_{66}$, both the highest and the lowest growing rates were greater $\left(72 \mathrm{~kg} \mathrm{DM} \cdot \mathrm{ha}^{-1} \cdot \mathrm{d}^{-1}\right.$ in spring and $11 \mathrm{~kg} \mathrm{DM} \cdot \mathrm{ha}^{-1} \cdot \mathrm{d}^{-1}$ in winter) than those of the nonfertilized native grassland. In this way, during the cool season $\mathrm{P}_{66}$ growing rate was $340 \%$ higher than nonfertilized treatment, while during the warm season $\mathrm{P}_{66}$ growing rate was $44 \%$ higher than nonfertilized treatment. Therefore, the distribution of forage biomass was better balanced throughout the year, and winter forage shortage was reduced. Although rainfall measured in March 1999 was higher than the average March rainfall (Fig. 1), and this might have contributed to the increase of cool season $A N P P$, water availability is usually not a restriction for growth during the cool season in this region.

Native legumes of Flooding Pampa rangelands have very low cover and little response to fertilization (Collantes et al. 1998). However, two exotic legumes, L. tenuis and T. repens, have naturalized in the region. Both species are frequent in these grasslands, but their contribution to forage production is scarce without fertilization. Previous results have been contradictory; some authors found increase of legume cover when $\mathrm{P}$ was supplied (Collantes et al. 1998), but others found decrease of this group (Mendoza et al. 1983). In this experiment $\mathrm{P}_{29}$ increased productivity of naturalized legumes by almost 5 -fold in native and 8-fold in old tall fescue grasslands, while $\mathrm{P}_{66}$ increased productivity by 20 -fold in both grasslands. In spite of the significant increase in legume productivity, their contribution to total grassland production stayed low, ranging from $1 \%$ in nonfertilized treatment to $6 \%$ under $\mathrm{P}_{66}$. Nevertheless, their impact may be important considering the contribution of biomass with high $\mathrm{N}$ content to the consumption of poor quality forage, and the increase of soil $\mathrm{N}$ pool via symbiotic fixation, a crucial mechanism in this grassland to maintain a positive balance of nutrient and ensure sustainability (Chaneton et al. 1996; Rubio et al. 1997). The response of these legumes to $\mathrm{P}$ supplied by spread fertilization may be related to several features:

1) The superficial distribution of roots of L. tenuis (Miñón et al. 1990) and T. repens (Whitehead 2000; Scheneiter 2001) confer to these species an advantage to absorb $P$ from the superficial soil horizon, respective to species with deeper root systems.

2) As natural reseeding is an important mechanism to ensure persistence of both legumes (Montes 1988; Scheneiter 2001), the higher availability of $P$ in the superficial soil horizon promotes seedling establishment.

3) Legumes are significantly favored when the concentration of available $\mathrm{P}$ near the active roots increases because of their low number of branch roots, total amount of root material, and the low number and length of root hairs per unit length of root, respective to grasses (Whitehead 2000).

ANPP of old tall fescue grassland didn't vary with fertilization because the main component, the perennial $\mathrm{C}_{3}$ grass $F$. arundinacea, was not affected by $\mathrm{P}$ addition. This result is coincident with other experiments applying $\mathrm{P}$ in fescue pastures (Maddaloni et al. 1984; Josifovich 1989). Perennial $C_{4}$ grasses, which contributed little to old tall fescue grassland production $(4 \%-13 \%)$, responded inconsistently to $\mathrm{P}$ addition. The superficial location of $\mathrm{P}$ supplied by broadcast fertilization at the soil surface makes this nutrient unavailable to the deeper root system of perennial grasses such as tall fescue and $\mathrm{C}_{4}$ grasses. Furthermore, annual grasses, which would be able to absorb P with their shallower root systems, were absent in this grassland. In consequence, the same lack of response of perennial grasses to $\mathrm{P}$ fertilization was met both in native and in old tall fescue grasslands.

Long-term residual effects of $\mathrm{P}$ were reported in other native or cultivated grasslands (Henkin et al. 1996; Quintero et al. 1997; Osman et al. 1999; Marino and Berardo 2005). Although studies of residual effect of $\mathrm{P}$ in Flooding Pampa region are extremely scarce, Collantes et al. (1998) reported a residual effect one year after fertilization on legume cover. In this experiment a residual effect that maintains during some years a higher contribution of annual $C_{3}$ grasses and legumes in the grasslands may be expected considering the higher $\mathrm{P}$ doses included of a slow release P fertilizer (rock phosphate).

\section{Implication for Livestock Management}

In the commercial farm where this experiment was conducted, a rotational grazing system such as that described by Jacobo et al. (2000) was implemented in 1996 together with P fertilization of a portion (1500 ha) of old tall fescue grasslands and native grasslands with high frequency of valuable forage species. As a consequence of these practices, the stocking rate increased gradually from $0.6 \mathrm{AU} \cdot \mathrm{ha}^{-1}$ in 1995 to 1.2 $\mathrm{AU} \cdot \mathrm{ha}^{-1}$ in 1999 , while meat production increased from $100 \mathrm{~kg} \cdot \mathrm{ha}^{-1} \cdot \mathrm{y}^{-1}$ in 1995 to $170 \mathrm{~kg} \cdot \mathrm{ha}^{-1} \cdot \mathrm{y}^{-1}$ four years later. This represented a stocking increase of approximately $60 \%$ and a secondary production increase of $78 \%$, compared to the average stocking rate and meat production of the Flooding Pampa region, respectively. We conclude that combining a grazing system that promotes the earlier establishment of L. multiflorum (Jacobo et al. 2000) with P fertilization of the Flooding Pampa native grassland allows increased productivity and reduced winter forage shortage, with the concomitant increase of carrying capacity and secondary production. The increase of legume contribution when both old tall fescue and native grassland are P fertilized 
may allow higher consumption and utilization rates by cattle and may increase $\mathrm{N}$ pool of soils via symbiotic fixation. We suggest that it is possible to achieve productivity and sustainability goals combining rotational grazing with $\mathrm{P}$ fertilization.

\section{ACKNOWLEDGMENT}

We are very grateful to Rodolfo Golluscio, who greatly improved an earlier draft of this manuscript.

\section{LITERATURE CITED}

ABe, K., And Y. OzaKı. 1998. Comparison of useful terrestrial and aquatic plant species for removal of nitrogen and phosphorus from domestic wastewater. Soil Science and Plant Nutrition 44:599-607.

Agnusdel, M. G. 1999. Analyse de la dynamique de la morphogenèse foliaire et de la défoliation de plusieurs espèces de graminées soumises à un pâturage continu dans une communauté végétale de la Pampa Humide (Argentine) [thesis]. Lorraine, France: Institut National Polytechnique de Lorraine. 108 p.

Aydin, I., AND F. Uzun. 2005. Nitrogen and phosphorus fertilization of rangelands affect yield, forage quality and the botanical composition. European Journal of Agronomy 23:8-14.

Brockway, D. G., G. L. Wolters, H. A. Pearson, R. E. Thill, V. C. Baldwin, and A. MARTIN. 1998. Understory plant response to site preparation and fertilization of loblolly and shortleaf pine forests. Journal of Range Management $51: 47-54$.

Bustos, J., M. Colabelli, and M. Agnusdel. 1998. Crecimiento de un pastizal natural de la Pampa Deprimida bonaerense bajo diferente disponibilidad de agua y nitrógeno. 2. Composición botánica y acumulación de forraje primaveroestival, Buenos Aires, Argentina. Asociación Argentina de Producción Animal, 22sd Congreso Argentino de Producción Animal, 14-16 October 1998. Río Cuarto, Argentina: Asociación Argentina de Producción Animal, Abstract. p. 124-125.

Cahuépé, M., And L. Hidalgo. 1991. Especies forrajeras naturales de la Depresión del Salado. Revista del Consorcio Regional de Experimentación Agrícola 149:1-19.

Chaneton, E. J., J. H. Lemcoff, and R. S. Lavado. 1996. Nitrogen and phosphorus cycling in grazed and ungrazed plots in a temperate subhumid grassland in Argentina. Journal of Applied Ecology 33:291-302.

Colabelli, M., M. Agnusdel, A. Mazzanti, and M. Labreveux. 1998. El proceso de crecimiento y desarrollo de gramíneas forrajeras como base para el manejo de la defoliación. Boletín Técnico 148. Estación Experimental Agropecuaria Balcarce. Balcarce, Argentina: Instituto Nacional de Tecnología Agropecuaria. $21 \mathrm{p}$.

Collantes, M. B., S. L. Stoffella, H. D. Ginzo, and M. Kade. 1998. Productividad y composición botánica divergente de dos variants florísticas de un pastizal natural de la Pampa Deprimida fertilizadas con N y P. Revista de la Facultad de Agronomía, la Plata 103:45-59.

Costa, J. L., And F. O. García. 1997. Respuesta de un pastizal natural a la fertilización con fósforo y nitrógeno en un natracuol. Revista de Investigaciones Agropecuarias 28:31-39.

Deregibus, V. A., E. J. Jacobo, and A. M. Rodríguez. 1995. Improvement in rangeland condition of the Flooding Pampa of Argentina through controlled grazing. African Journal of Range and Forage Science 12:92-96.

Durand, J. L., F. Gastal, S. Etchebest, A. C. Bonnet, and M. Ghesquière. 1997. Interspecific variability of plant water status and leaf morphogenesis in temperate forage grasses under summer water deficit. European Journal of Agronomy 7:99-107.

Fernández Greco, R. C., and M. Agnusdel. 2004. Fertilización nitrogenada en un pastizal de la Pampa Deprimida: acumulación de forraje y composición botánica. Revista Argentina de Producción Animal 24:199-206.
Fernandez Greco, R. C., and A. E. Mazzanti. 1998. Respuesta de un pastizal natural de la Pampa Deprimida a la fertilización nitrogenada, Buenos Aires, Argentina. Asociación Argentina de Producción Animal, 22sd Congreso Argentino de Producción Animal, 14-16 October 1998. Río Cuarto, Argentina: Asociación Argentina de Producción Animal, Abstract. 118 p.

Fernandez Greco, R. C., A. Mazzanti, and H. E. Echeverría. 1995. Efecto de la fertilización nitrogenada sobre el crecimiento de forraje de un pastizal natural de la Pampa Deprimida bonaerense (Argentina). Revista Argentina de Producción Animal 15(3-4):173-176.

Ferreira de Quadros, F. L., D. Guerra Brandinelli, A. G. Schirmer Pigatto, and M. Gomes DA Rocha. 2005. Morfogênese de Lolium multiflorum Lam. e Paspalum urvillei Steud sob níveis de adubação de fósforo e potássio. Ciencia Rural 35:181-186.

Ginzo, H. D., M. B. Collantes, and O. H. Caso. 1982. Fertilization of a native grassland in the "Depresion del Rio Salado," Province of Buenos Aires: herbage dry matter accumulation and botanical composition. Journal of Range Management 35:35-39.

Henkin, Z., I. Noy-Meir, U. Kafkafi, M. Gutman, and N. Seligman. 1996. Phosphate fertilization primes production of rangeland on brown rendzina soils in the Galilee, Israel. Agriculture, Ecosystems and Environment 59:43-53.

Hidalgo, L., and M. Cahuépé. 1991. Producción de forraje de las comunidades de la depresión del Salado. Revista del Consorcio Regional de Experimentación Agrícola 149:58-62.

Jacobo, E. J., A. M. Rodríguez, N. Bartoloni, and V. A. Deregibus. 2006. Rotational grazing effects on rangeland vegetation at a farm scale. Rangeland Ecology \& Management 59:249-257.

Jacobo, E. J., A. M. Rodriguez, J. L. Rossi, L. P. Salgado, and V. A. Deregibus. 2000. Rotational stocking and production of Italian ryegrass on Argentinean rangelands. Journal of Range Management 53:483-488.

Josifovich, J. A. 1989. Producción de carne sobre una pastura de festuca alta fertilizada en 9 de Julio. Boletín Técnico 80. Estación Experimental Agropecuaria Pergamino. Pergamino, Argentina: Instituto Nacional de Tecnología Agropecuaria. $17 \mathrm{p}$.

Kalmbacher, B., and F. Martin. 1996. Shifts in botanical composition of flatwoods range following fertilization. Journal of Range Management 49:530-534.

LeE, H. S., AND I. D. LeE. 2000. Effect of $N$ fertilizer levels on the dry matter yield, quality and botanical composition in eight-species mixtures. Korean Journal of Animal Science 42:727-734.

LEón, R. J. C. 1975. Las comunidades herbáceas de la Región Castelli-Pila. Monografías Comisión de Investigaciones Científicas 5:75-107.

Maddaloni, J., O. Bertín, AND J. A. Josifovich. 1984. Fertilización fosforada de una pastura de festuca (Festuca arundinacea) y su efecto sobre los animales. Revista Argentina de Producción Animal 4:399-409.

Marino, M. A., and A. Berardo. 2005. Alfalfa forage production under different phosphorus supply strategies. Better Crops 89(4):22-25.

Melgar, R., and L. N. Castro. 2005. Fosfatos. In: Proy. CYTED XIII-2 Documento final. Available at: http://www.unsam.edu.ar/escuelas/posgrado/centro_ceps/ investigaciones/fertilizantes/Capitulo3.pdf. Accessed 8 February 2006.

Mendoza, R. E., D. H. Cogliatti, M. B. Collantes, and M. Kade. 1983. Efecto de la fertilización nitrógeno-fosfatada sobre el crecimiento otoño-invernal y la absorción de fósforo en tepes de un pastizal natural. Turrialba 33:311-320.

Miñón, D. P., G. H. Sevilla, L. Montes, and O. N. Fernandez. 1990. Lotus tenuis: leguminosa forrajera para la Pampa Deprimida. Boletín Técnico 98. Estación Experimental Agropecuaria Balcarce. Balcarce, Argentina: Instituto Nacional de Tecnología Agropecuaria. $16 \mathrm{p}$.

Montes, L. 1988. Lotus tenuis (revisión bibliográfica). Revista Argentina de Producción Animal 8:367-376.

Nichols, J. T., P. E. Reece, G. W. Hergert, and E. L. Mooser. 1990. Yield and quality response of subirrigated meadow vegetation to nitrogen, phosphorus and sulfur fertilizer. Agronomy Journal 82:47-52.

Oesterheld, M., and R. J. C. León. 1987. El envejecimiento de las pasturas implantadas: su efecto sobre la productividad primaria. Turrialba 37:29-35.

Osman, A. E., A. K. Salkini, and F. Ghassali. 1999. Productivity and botanical composition of Mediterranean grasslands in relation to residual phosphate. Journal of Agricultural Science 132:399-405. 
Perelman, S. B., R. J. C. León, and M. Oesterheld. 2001. Cross-scale vegetation patterns of flooding Pampa grasslands. Journal of Ecology 89:562-577.

Quintero, C., N. G. BoschetrI, AND R. A. BenAvidez. 1997. Efecto residual y refertilización fosfatada de pasturas implantadas en Entre Ríos. Ciencia del Suelo 15:1-5.

Rodríguez, A. 2004. Efecto de las condiciones ambientales y de las estrategias de pastoreo sobre la germinación y el establecimiento de ryegrass anual (Lolium multiflorum Lam). Consecuencias sobre la productividad invernal de los pastizales de la pampa Inundable [thesis]. Buenos Aires, Argentina: Facultad de Agronomía, Universidad de Buenos Aires. 60 p.

Rubio, G., M. A. Taboada, R. S. Lavado, H. Rimski-Korsakov, and M. S. Zubillaga. 1997. Acumulación de biomasa, nitrógeno y fósforo en un pastizal natural fertilizado de la Pampa Deprimida, Argentina. Ciencia del Suelo 15:48-50.

Sala, O. E., V. A. Deregibus, T. M. Schlichter, and H. Alippe. 1981. Productivity dynamics of a native grassland in Argentine. Journal of Range Management 34:48-51.
Scheneiter, 0. 2001. Trébol blanco. In: J. Maddaloni and L. Ferrari [eds.]. Forrajeras y pasturas del ecosistema templado húmedo de la Argentina. Lomas de Zamora: Universidad Nacional de Lomas de Zamora, Facultad de Ciencias Agrarias. p. 261-287.

Soriano, A., R. J. C. León, O. E. Sala, R. S. Lavado, V. A. Deregibus, M. A. Cahuépé, 0. A. Scaglia, C. A. Velázquez, and J. H. Lemcoff. 1991. Rio de La Plata grasslands. In: R. T. Coupland [ED.]. Ecosystems of the world: Natural grasslands: Introduction and Western Hemisphere. Amsterdam: Elsevier. p. 367-407.

Taboada, M. A., and R. S. Lavado. 1986. Características del régimen ácuico de un Natracuol de la Pampa Deprimida. Ciencia del Suelo 4(1):6671.

WhiteHEAD, D. C. 2000. Nutrient element in grassland: soil-plant-animal relationships. Cambridge: CABI Publishing. $369 \mathrm{p}$. 